専門医症例報告

中空型全部床義歯により上顎顎堤の高度吸収に対応した有床義歯補経症例

村上任尚

\title{
A Case Report of Prosthetic Treatment for Advanced Ridge Resorption by a Hollow Maxillary Complete Denture
}

Takahisa Murakami

抄 録

症例の概要 : 患者は 74 歳女性。顎堤吸収の進行への不安と咀嚼困難を主訴に来院した。治療用義歯を用 いて咀嚼機能を回復するとともに下顎位を決定し，上顎前歯部歯槽部を中空とした全部床義歯にて最終補 綴処置を行った。

考察：上顎枵堤が高度に吸収した患者の義歯補綴にあたり，義歯の体積と重量の増加は，しばしば維持力 の低下を招く。本症例では, 義歯床前歯部を中空化することにより, 重量を減じこの問題に対応した。最 終補綴後 3 年を経過するが, 審美性, 使用感に関する患者本人の満足度は高く, 良好に経過している。 結論：上顎高度顎堤吸収症例に対し，軽量化した義歯を適用することで良好な治療経過を得た。

和文キーワード

中空型全部床義歯, 高度顎堤吸収

\section{ABSTRACT}

Patient: A 74-year-old woman visited our hospital with a complaint of progressive residual ridge resorption and chewing difficulty. Improvement of masticatory function and determination of suitable mandibular position were carried out using a treatment denture. A hollow complete denture was adopted as the definitive denture of her upper jaw.

Discussion: Maxillary complete dentures for patients with severe ridge resorption have a tendency to be large in volume and mass, which may decrease retention of the dentures. In this case, retention was increased by hollowing out the anterior part of the denture base and decreasing its mass. Three years after receiving the final prosthesis, the patient is highly satisfied with the esthetics and sensation. Conclusion: This case report demonstrates that a favorable outcome can be obtained in a case of severe maxillary ridge resorption by insertion of a weight-saving complete denture.

\section{Key words}

hollow complete denture, severe ridge resorption 


\section{I．緒言}

前歯部の高度な顎堤吸収を伴う上顎無歯顎症例は, しばしば前方離開型を呈する上下顎堤の対向関係とつ ラビーガムの存在によって，義歯による補綴の難症例 とされる。

今回, 下顎に少数歯のみが残存している上顎高度顎 堤吸収患者に対し，内部を中空とすることで軽量化を 図った義歯を用いて, 審美性および機能に配慮し補綴 処置を行ったので報告する。

\section{II. 症例の概要}

患者：74 歳 (初診時)，女性.

初診日：2004 年 10 月.

主訴：上の前歯が見えなくなり，顎がどんどん瘦せ ていきそうで不安。噛みにくい.

既往歴 : 特記事項なし。

現病歴：10 年程前, 下顎両側臼歯部に骨増生ととも にインプラントを埋入し, 上下義歯（上顎: 全部床義歯, 下顎:インプラントオーバーデンチャー)を作製したが, 最近 5 年の間にほとんどのインプラントが動摇をきた し除去に至った。その後, 複数の歯科医院にて義歯を 作製するも，長期的な安定が得られず，上顎顎堤吸収 の進行への不安と, 咀嚼困難を主訴に当院を受診した。

現症：正面顔貌は左右対称。義歯未装着の状態では 中顔面部が著しく陥凹していた（図 1)。上顎は無歯顎 で，特に前歯部歯槽骨の骨吸収は前鼻棘にまで及んで おり，上下顎顎堤の対向関係は前方離開型を呈してい た。また，前歯部から小臼歯部にかけての広範囲にフ ラビーガムが存在し, 切歯乳頭のやや後方には発赤, び爛，および圧痛が認められた。下顎は，右側犬歯お よび小臼歯の 3 歯のみ残存していた（図 2). 初診時に 装着していた義歯は，咬合時に上顎前歯部の突き上げ を認めるとともに，咬合高径の不足と水平的顎間関係 の不正が疑われた。 また安静時においても, 上顎義歯 前歯切緑の位置は上唇下縁より上方に位置しており, 審美性は不良であった。

検査結果 : パノラマX 線写真上でも, 上顎歯槽骨の 著しい吸収が認められた(図 3)。パノラマX線写真は, 本院来院直前の前医受診時のもの（当院初診時のもの は東日本大震災にて消失）で，周囲に垂直性の骨吸収 が認められる下顎右側側切歯および左側インプラント は, 本院来院前に抜歯, 除去されていた。咀嚼筋群お よび顎関節部に運動痛や圧痛はなく, 開閉口路はス卜 レートで, 開口障害や関節雑音などの所見は認められ なかつた。

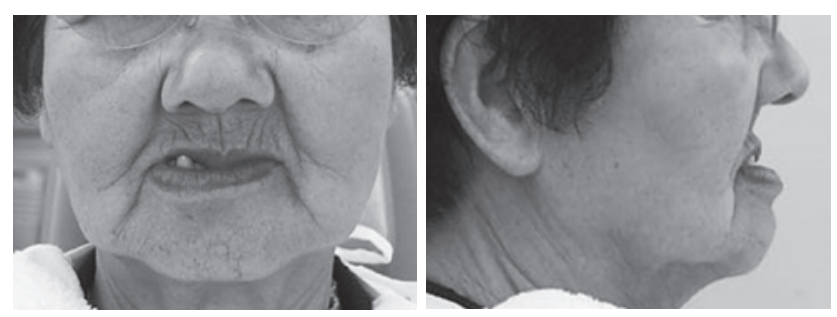

図 1 Lower-facial views at the first examination 初診時の顔貌写真

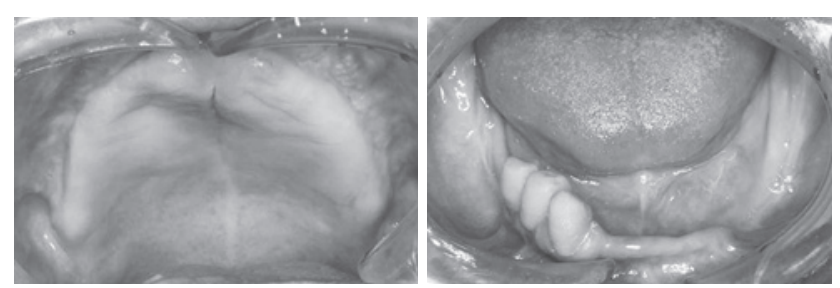

図 2 Intraoral views at the first examination 初診時の口腔内写真

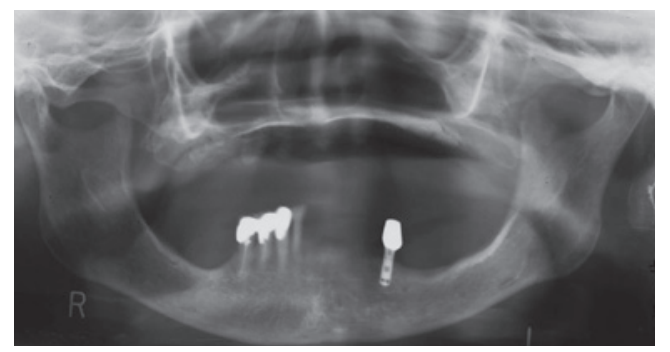

図 3 Panoramic radiography before a visit to the hospital 来院直前のパノラマX 線写真

診断：義歯の不正咬合および形態不良に起因する審 美・咀嚼障害.

\section{III，治療内容と経過}

治療方針および計画：多数歯欠損および高度顎堤吸 収に対する選択肢として, 可撤性義歯による補綴処置 に関する説明に加え, 全身状態に問題がないため, 義 歯の支持, 維持, 把持の観点から, インプラントの利 用 ${ }^{1)}$ およびインプラント選択時の骨増生処置の可能性 を提示するとともに，利点欠点について説明を行った。 しかし, 以前行った下顎臼歯部の骨増生およびインプ ラント埋入の経緯から，インプラント治療は避けたい と強く希望されたため, 可撤性義歯のみで補綴処置を 行うことで最終的な同意を得た。

咬合高径の低下と水平的顎位の不正が疑われたた め, 最終補綴に先立ち, それらの診断および改善を目 的として治療用義歯を製作することとした。治療用義 歯は, 初診時に装着していた義歯が金属床で改造が困 

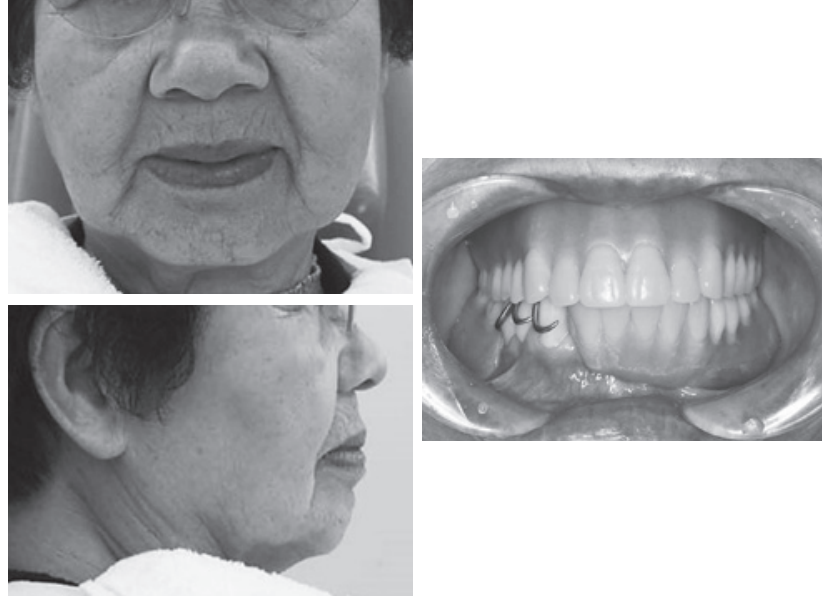

図 4 Intraoral and lower-facial views with treatment denture

治療用義歯装着時の口腔内写真と顔貌写真
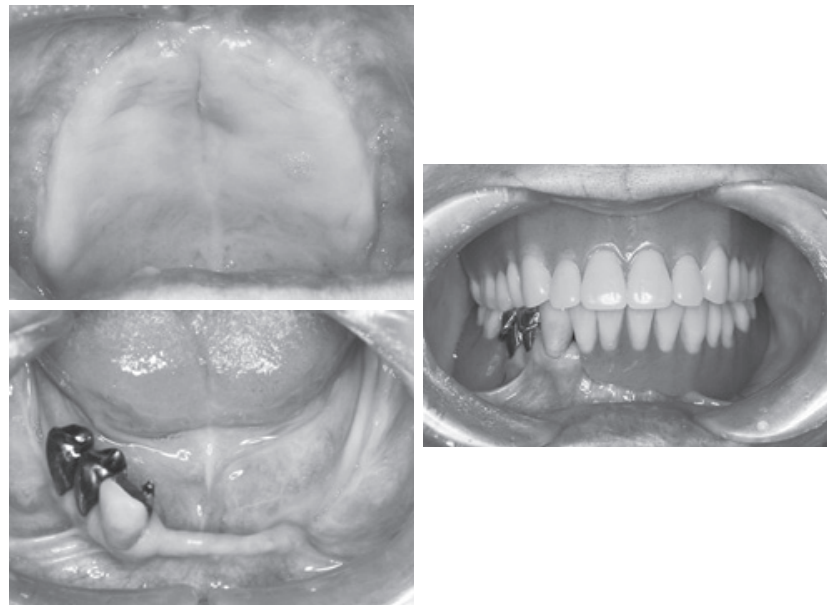

図 5 Intraoral views after prosthetic treatment 補綴処置終了時の口腔内写真
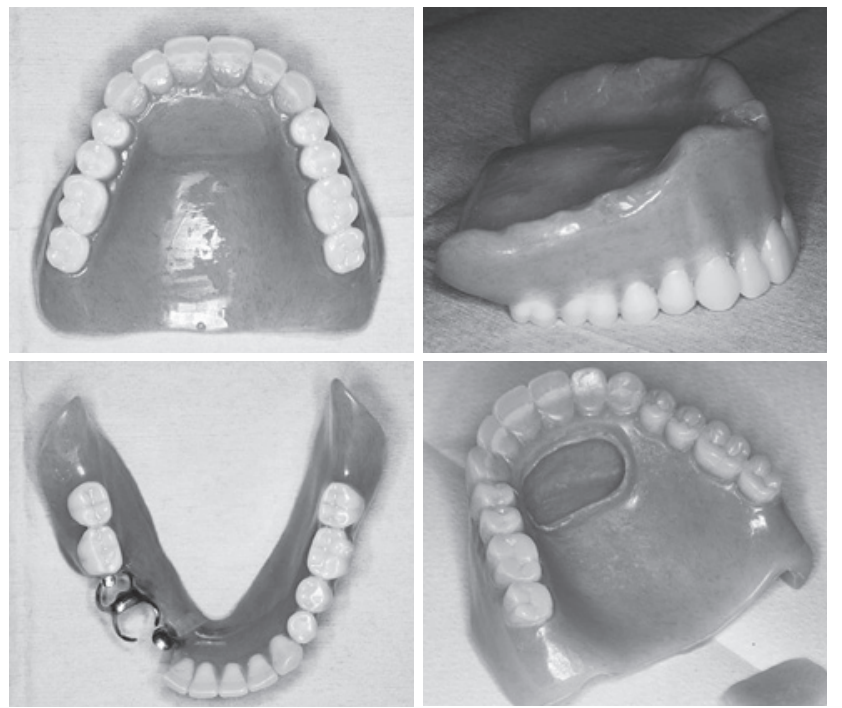

図 6 Hollow complete denture 中空型の全部床義歯
難であること，形態の大幅な変更が必要であることを 考慮し，一般的な義歯製作過程を経て新たに製作した。 上下顎に治療用義歯を装着し，適切な咬合高径および 被蓋関係を確保し審美性を改善するとともに下顎位の 安定を図り，その後最終補経に移行した。最終補綴移 行の際には，著しく吸収した顎堤を回復するために容 積が増大する上顎義歯の重量の増加によって増してし まう離脱力を減少させ，長期的に義歯を安定させる目 的で, 前歯部歯槽部を中空にして軽量化することとし た。

処置内容：平成 16 年 12 月，上下顎に治療用義歯 を装着した（図 4)。通常，フラビーガム部は印象およ び義歯重合時にリリーフを行い晈合圧の負担をさせな $い^{2)}$. しかし，本症例の場合，フラビーガムの範囲が 広く，全ての範囲をリリーフすることは困難であった。 そのため, リリーフは特に炎症所見が認められた切歯 乳頭部付近と口蓋㱀璧部のみとし, 安静時から機能時 にかけての上顎義歯のやや上前方への変位を許容する こととした。 上顎前歯部切縁の位置は安静時の上唇下 縁の下方 $1 \mathrm{~mm}$, 咬合平面はカンペル平面と平行とし, 垂直的および水平的顎位は，下顎安静位，䜩下位，顔 貌所見，本人の感覚を総合的に評価して決定した。咬 合様式はフルバランスドオクルージョンとし，人工歯 の咬頭傾斜はやや緩めに設定した。側方力を可及的に 少なくするとともに，機能咬頭が接する対合歯の咬頭 傾斜を前後的に平坦化して前後方向の自由度を与える ことで, 機能時の義歯の沈下に伴って生じる上顎義歯 の変位の前後においても臼歯部の咬合支持を確保し, 安定した咬頭嵌合位および咬合平衡が得られる咬合面 形態とした。また, 通法通り $\mathrm{S}$ 字状隆起を付与し, 発 音についても観察を行うこととした。 1 〜 3 カ月ごと の調整と経過観察を行い，旧義歯と比較し増加した咬 合高径への順応と下顎位の安定が認められ, 咀嚼, 発 音等の機能および審美性にも問題がなく，患者の満足 が得られたため, 平成 20 年 2 月, 最終補綴に移行した。 適切なアンダーカットを確保し，新たに設定された咬 合平面に咬合面形態を調和させるため，下顎残存歯の 全部鋳造冠および硬質レジン前装鋳造冠による再補綴 を行った後, 平成 21 年 7 月に上下顎最終義歯装着を 完了した（図 5)。下顎位及び咬合様式は，可及的に治 療用義歯の状態を反映させた。上顎義歯前歯部歯槽部 の中空部は，ろう義歯の口蓋㱀譬部に陥凹部を形成す るとともに，蓋となるパーツを別に用意し，重合後に 常温重合レジンを用いて接合することで閉鎖空間とし た(図6).

術後の経過：最終補綴終了後 3 年間，概放 3 力月間 


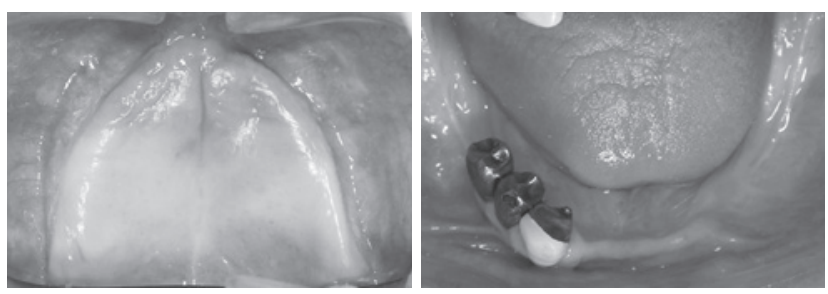

図 7 Intraoral views at 3 years after prosthetic treatment 最終補綴終了 3 年後の口腔内写真

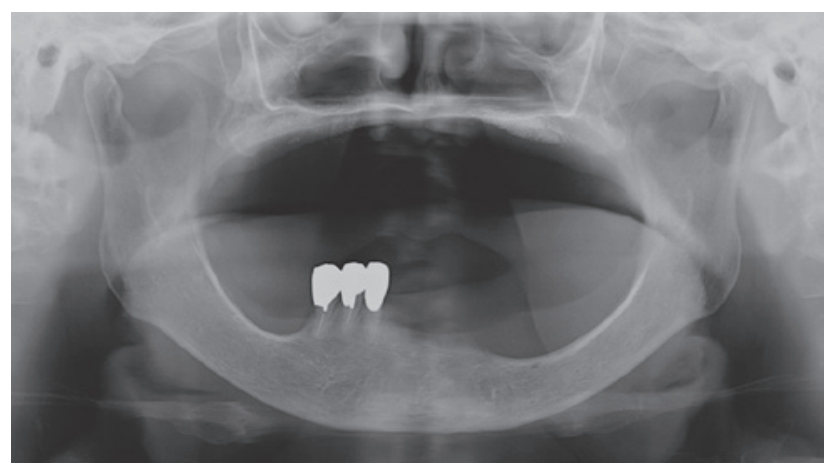

図 8 Panoramic radiography at 3 years after prosthetic treatment

最終補綴終了 3 年後のパノラマX 線写真

隔でメンテナンスを続けている。装着約 1 年半後に上 顎義歯の維持力低下に対し訴えがあり視診および触診 にて, フラビーガムの容積と被圧変位量の減少が認め られたため，部分的なリラインを行った。 その後維持 力の低下も認められず経過は良好である（図 7，8）。

\section{IV. 考 察}

高度顎堤吸収患者への義歯補綴にあたり，上下顎顎 堤の対向関係が前方離開型である場合，機能時の義歯 の前方への推進力を考慮しなければならない.これに 対しては，やや咬合を低位にして前方離開の程度を減 じたり，咬合平面をカンペル平面に比ベやや後ろ下が りに設定することで，咬合力方向を顎堤に出来るかぎ り垂直に近い方向に修正するといった対応が経験則で なされている。しかし過度の低位咬合は，顎関節を中 心とした下顎の回転によってオトガイ部を上前方へ変 位させ，結果的に上顎前歯部に加わる咬合力の作用方 向は義歯の安定に不利なものとなる。また，本症例で は前歯部顎堤の吸収に伴う審美障害が主訴の一つで
あった。 そこで本症例では, 適切な咬合高径を回復す るとともに前歯部の審美性を確保するため, 通法通り 上顎前歯切縁を上唇下縁よりやや下方に設定し, 上顎 義歯前方部の体積の増大を許容した。この審美性の確 保と義歯の不安定さにつながる義歯体積・重量の増大 という相容れない問題に対しては, 前歯部歯槽部を中 空とすることで対応を試みた。上顎義歯は軽いほど, 下顎義歯は重いほど安定するとされており ${ }^{3)}$ ，今回の 処置も上顎義歯の重量を中空にしなかった場合と比較 して約 15\% 軽減させるとともに, 重心を後方に移動 することにより義歯安定の一助となったと考えてい る. 機能時の義歯の前方への推進力に対しては, 上述 のとおりの咬合を付与することで対応し, 良好な結果 が得られた。比較的長期にわたる治療用義歯の使用に より, フラビーガムが減少し, 炎症の消退がみられた ことは, 機能時に適切な臼歯部の咬合支持を確保した ことで，前歯部粘膜への過剩負担が軽減した結果と考 えられる。義歯管理時には, 顎堤や咬合関係の変化に 対する経過観察とともに, 床用レジンの吸水性に由来 する中空部への水の浸入に対してもしかるべき管理と 対応が必須であると思われる。

\section{V. 結 論}

上顎高度顎堤吸収症例に対し, 機能時における咬合 力の作用方向に配慮するともに, 前歯部歯槽部を中空 にし軽量化した義歯を適応することで，良好な治療経 過を得た。

\section{文献}

1) 山縣健佑, 黒岩昭弘. 図説無歯顎補綴学. 東京: 学建 書院；2004，295-302.

2）細井紀男，平井敏博，長岡英一，赥川安正，鈴木哲也， 大川周治。コンプリートデンチャーテクニック第 6 版. 東京：医歯薬出版；2011，43-44.

3) 中沢 勇. 全部床義歯学. 東京：永末書店；1960, 437.

著者連絡先 : 村上 任尚

干 980-8575 宮城県仙台市青葉区星陵町 4-1

Tel/Fax: 022-717-8397

E-mail: t-murakami@dent.tohoku.ac.jp 